\title{
Descriptive Writing Style: The Use of Critical Incidents within Higher Education Settings for Further Professional Development
}

\author{
Husam Helmi Alharahsheh* \\ Lecturer in business Management at University of Wales Trinity Saint David - London and Senior visiting lecturer across several UK \\ and international Higher Education Institutions, College St, Winchester House, 11 Cranmer Rd, London SW9 6EJ, United Kingdom
}

\author{
${ }^{*}$ Corresponding Author \\ Husam Helmi Alharahsheh

\section{Article History} \\ Received: 15.10 .2019 \\ Accepted: 24.10 .2019 \\ Published: 31.10 .2019
}

\begin{abstract}
This brief paper is providing an example of using a critical incident experience to write descriptively, and to use as a method for further enhancement and development of professional practice within higher education sittings as well as other sittings. The key purpose of this paper is to critically reflect on the use of this writing style, and how it would potentially influence further development of a student, educator and industry professional. The paper is supported by different academic papers from the literature to support the evaluation, reflection and conclusions of the work based on the critical incident provided.
\end{abstract}

Keywords: Descriptive writing, critical incident, development, reflection, higher education.

\section{INTRODUCTION}

This brief paper will apply a descriptive writing style to further analyse a critical incident relating to a teaching practice at the early stages of teaching experience of an educator within higher education settings. The key purpose of this paper is to critically reflect on the use of this writing style, and how it would potentially influence further development as a student, educator and industry professional. I have utilised the descriptive writing style as given below in the event section. Application of this writing style would further enable to explore key modes and elements that should be considered to develop.

\section{The Event}

It was a study skills class during the first week of the semester, majority of students in the class were just starting their degrees across the business management law faculties, with a class of nearly 25 students coming from diverse backgrounds such as age range, nationality, gender, education levels and life experiences. Students were rushing to the class to reserve their seats; some passionately were aiming to be in the front and others were deliberately aimed to be at the back of the class. The session started at 9:00 AM as an introductory session for the whole module. Everyone was very attentive and had alerted body language mixed with excitement and curiosity for the educational journey ahead considering that this was just their first week at the university. Students were very polite and shy in their contribution whenever I was asking for contributions to make the session more interesting and informative. Suddenly and while I was going through my introductory information for the module using a sense of humour, a student opened the door of the small class 30 minutes late with clear facial expression of anger and unhappiness. He seemed to be very demotivated and lacked interest to be in the class. He sat down at the back of the class and very rudely started talking to the student sitting next to him. After around 5 minutes of his arrival and without any signs of asking for permission, he suddenly shouted: "Why am I doing this module? this module is not relevant to my studies". My happy and communicative facial expressions changed as I heard the shouting. Then, I decided to stop what I was focused on with the rest of the class, and responded to him promptly: "It is just week one and you will see later how this relates to your studies", and then asked him to introduce himself briefly. Through his brief and careless introduction I understood that he is on his second attempt for this module as he failed the assessments two times in the last two semesters. I could understand through his unhappy facial expression and body language that he needed clarification, and was unhappy about the module based on his previous experience. However, at that moment of time I felt that I need to clarify it and keep the whole class engaged in the session. Therefore, I smiled and had to keep the conversation with him short and simple to continue with my topic planned for the class to avoid any further development in the situation. I had to be firm in my communication with him to

Copyright @ 2019: This is an open-access article distributed under the terms of the Creative Commons Attribution license which permits unrestricted use, distribution, and reproduction in any medium for non commercial use (NonCommercial, or CC-BY-NC) provided the original author and source are credited. 
avoid any further disruption in the class that would maybe encourage other shocked and curious students to contribute to it. $A$ few minutes later, I had a glance at the noisy clock opposite to me and realized it was the time for a break. The moment I mentioned it to the class excitingly, majority of students stood up and were waiting for me to stop my talk to leave for their short break apart of him (The late and disruptive student). As they left they strangely and angerly starred at him, however, he kept calm and stayed in his seat. I approached him with very mixed feelings of anger and sympathy as he previously failed the module twice and decided to have a conversation with him. Before I even arrive to his seat and start talking, he said gently with tears in his red eyes: "Sir, I am sorry and I apologize", and then expressed his negative previous experience with the assessment and the whole module. I spent the whole break time explaining to him the importance of the module and that he should learn from his previous experience to pass this time.

\section{Evaluation}

The presentation of this short experience in a descriptive writing, and within a learning and teaching context at university level, is aimed to reflect the author's own observation as well as learning from the experience. The details above provided description of several developments experienced in a specific place, objects, and group [1]. However, at a certain stage of the description, the attention was turned towards one new character as the late and disruptive student. Descriptions were supported by expositions, arguments and narration. Inclusion of several factors or modes such as place, objects, group and later the character, enable the author to write more descriptively [1] and provide more colour and life to the story [2]. The aim of this writing style is to ensure the reader's engagement with the story including key factors or modes such as the place or the character.

It is argued by [3] that description should reflect full story or observation to appeal to readers as every scene should provide key details pertaining the surrounding environment. Therefore, the author aimed to provide deep details within the introductory statement to pass experience of key factors to the reader. However, the main character in the story was not introduced in the beginning and was kept as an element of surprise to the reader to enable further communication to the feelings and overall engagement in the story.

The writing above was developed to ensure achievement of key points summarised as the following [4]: Firstly, the introduction of the writing has included a base for the case including introduction of the context, place and group, and were later described in more details. Secondly, the writing above aimed to appeal to the reader's senses as it tried to create images in the reader's imagination. Thirdly, towards the conclusion, there was a peak mention of several developments such as students' rushing for the break while staring at the late and disruptive student, and the apologetic sense of the main character as he realized his mistakes of being unpolite.

In the description of the event above it is clear that three key voices could be heard as the following: Firstly, the teacher's voice as the educator and facilitator of the class. Secondly, the whole group of the new students. Thirdly, the late and disruptive student. Students' behaviour in class can influence the way educators engage their students within higher education settings [5]. It is also important to note that it is important for educators to know students' experiences and backgrounds at early stages of delivery of classes in higher education, this would certainly enable active and deep engagement during the process [6].

\section{Reflection and Conclusion}

In this short paper, the author has reflected experience and observation illustrating a critical incident context relating to higher education setting in terms of learning and teaching environment. The reflection included several key perspectives as the following:

- The lecturer's perspective as the lecturer in charge of session delivery.

- The whole group's perspective in the form of the other students that were present in the class (around 25 students).

- The character in the form of the late and disruptive student that came 30 minutes late.

This experience as detailed in the event section above highlighted critical incident within higher education learning and teaching setting. Therefore, equally reflection on such experiences can develop ability of practitioners, educators as well as students to be more reflective through a non-traditional writing style as provided in the event description [7], which is opposite to the traditional models of reflection commonly used such as $[8,9]$.

Selecting this descriptive writing style can certainly challenge individuals to read more searching for relevant examples and connections. This can enable individuals to literally write a traditional experience that individuals can have within higher education setting on even in other sittings in a non-traditional writing style in the form of descriptive writing. Therefore, the author had to read several examples such as [10-12] to observe key patterns in writing descriptively. However, these examples were mainly fiction writing modes. Skills developed through using such a writing style can further enhance authors ability to think deeply while applying creative and innovative approaches to communicate to readers. Therefore, this can also help educators to use key ideas to enhance innovative curriculum development within higher education settings to further match the various needs of students in higher education $[6,13]$. 


\section{References}

1. Crews, F. (1977). The Random House handbook. New York: Random House.

2. Spencer, L. (2004). A step by step guide to descriptive writing. New York: The Rosen publishing group.

3. Soule, S. (2016). The writer's guide to vivid settings and characters. FWT.

4. Doherty, B., \& Jaffe, C. (2002). Descriptive writing. Hawthorne, NJ: Educational Impressions.

5. Marton, F., \& Säaljö, R. (1976). On qualitative differences in learning-ii Outcome as a function of the learner's conception of the task. British Journal of educational Psychology, 46(2), 115-127.

6. Biggs, J., \& Tang, C., (2007). Teaching for quality learning at university. 3rd ed. Maidenhead: SRHE \& Open University Press.

7. Mohammed, R. (2016). Critical incident analysis: reflections of a teacher educator. Research in Teacher Education, [online] 6(1), 25-29. Available at: https://www.uel.ac.uk/Schools/Cass/Research/Research-in-Teacher-Education/Volume-6-No-1-May2016 [Accessed 14 June. 2019].

8. Kolb, D. A. (2014). Experiential learning: Experience as the source of learning and development. FT press.

9. Gibbs, G. (1988). Learning by Doing: A guide to teaching and learning methods. Further Education Unit. Oxford Polytechnic: Oxford.

10. Kerouac, J. (2012). Desolation angels. London: Penguin Books.

11. Bradbury, R., \& Mugnaini, J. (2007). The Halloween tree. New York: Del Rey Books.

12. Jansson, T. (1974). Moominvalley in November. London: Puffin Books.

13. Biggs, J. B. (1999). Teaching for quality learning at university. Open University Press. 